Paweł Pałasiński

\title{
AMOR FATI FRYDERYKA NIETZSCHEGO (KONIECZNOŚĆ I PRZYPADKOWOŚĆ LOSU CZŁOWIEKA)
}

\section{WPROWADZENIE}

Jednym ze znanych haseł filozofii Nietzscheańskiej jest amor fati - umiłowanie losu. Jednak amor fati w rozważaniach autora Poza dobrem i złem jest końcowym „produktem” jego myślenia o możliwym ujmowaniu przez człowieka wydarzającego się świata. Ujęcie to implikuje rozumienie świata jako albo całkowicie przypadkowego, albo przesyconego deterministyczną koniecznością następowania po sobie określonych zdarzeń. Słowem: człowiek może odbierać swoje życie jako niczym nieuwarunkowane bądź całkowicie zdeterminowane.

Jednak, co wydaje się najważniejsze, Nietzsche w swym haśle amor fati nakłada na człowieka niejako obowiązek umiłowania losu, który jest nierozerwalnie związany z jego egzystencją. $\mathrm{W}$ formule amor fati niemiecki filozof stawia przed człowiekiem nie lada wyzwanie. Los, który mamy umiłować, obfituje zarówno w chwile największej radości, jak również w momenty najczarniejszej rozpaczy. Mamy tu więc do czynienia ze szczególnego 
rodzaju wymogiem, który - jak postuluje Nietzsche - ludzie powinni przyjąć tak, jak uczynił on sam ${ }^{1}$.

W niniejszej pracy zostanie podjęta próba odpowiedzi na niektóre pytania, jakie rodzi formuła amor fati na gruncie filozofii Nietzscheańskiej. Rozważymy trzy następujące pytania:

1. Czy los, który człowiek musi zaakceptować lub pokochać, jest żelazną koniecznością czy całkowitym chaosem przypadkowości?

2. W jaki sposób człowiek powinien ujmować los, aby mógł go pokochać? Główną wątpliwością, jaką rodzi postulat absolutnego umiłowania losu, jest to, jak kochać zdarzenia, które są dla człowieka bolesne; których człowiek nie chciałby nigdy przeżyć, a które jednak pojawiły się w jego życiu. Zdarzenia tego typu zostały niejako zesłane człowiekowi przez los. Czy da się w takim wypadku faktycznie zastosować formułę amor fati? Czy wydarzające się w życiu człowieka tragedie można zaakceptować, a nawet pokochać?

3. Trzecie i najważniejsze, zdaniem autora niniejszej pracy, pytanie brzmi: dlaczego Nietzsche domagał się, aby ludzie kochali swój los niezależnie od jego realnego kształtu? Odpowiedź na to pytanie odsłoni szerszy horyzont myślenia niemieckiego filozofa o człowieku oraz ukaże sposoby życia, prowadzące człowieka do życia szczęśliwego, czyli zaakceptowania i pokochania swego losu.

\section{MIĘDZY PRZYPADKOWOŚCIĄ A KONIECZNOŚCIĄ LOSU}

Przypadkowość jest w filozofii Nietzscheańskiej założona a priori, gdyż autor Zmierzchu bożyszcz był zdania, iż świat jest bezkres-

${ }^{1}$ Zob. F. Nietzsche, Ecce Homo. Jak się staje - kim się jest, przeł. L. Staff, Zielona Sowa, Kraków 2006, s. 73. 
nym stawaniem $\operatorname{się}^{2}$. Założenie to zdaje się zawierać w sobie twierdzenie, iż świat jest przesycony zmiennością, która nie posiada żadnej trwałej zasady, co implikuje całkowitą przypadkowość wszystkich zdarzeń. Nietzsche pisał jednak:

Istnieje się w sposób konieczny, jest się cząstką przeznaczenia, należy się do całości, istnieje się w całości - nie istnieje nic, co nasz byt mogłoby osądzać, mierzyć, porównywać, potępiać, gdyż oznaczałoby to osądzać, mierzyć, porównywać, potępiać całość... A przecież nie ma niczego poza całością! ${ }^{3}$.

Zatem autor Zmierzchu bożyszcz z jednej strony twierdzi, iż świat stawania się rządzi się całkowitą przypadkowością, zaś z drugiej, że „istnieje się w sposób konieczny”. Można więc zapytać, jaki właściwie charakter ma dla Nietzschego ludzka egzystencja: konieczny czy przypadkowy? Jak rozpatrywać los ludzki, który ma być przecież przedmiotem miłości człowieka i został opatrzony formułą amor fati?

Nietzsche pisał o świecie jako o „całości”, odrzucając jednocześnie ujęcie świata jako jedności czy sensorium ${ }^{4}$. Świat jest zatem całością szczególną, zmieniającą się, rządzoną przez nieubłagany, bezrozumny przypadek. Życie ludzkie - jako zaistniałe w tym heraklitejskim potoku stawania się - jest konieczne, gdyż, jak pisał Nietzsche, „jest się cząstką przeznaczenia”. Co oznacza to stwierdzenie autora Zmierzchu bożyszcz? Czy Nietzsche wierzył w przeznaczenie, które panuje nad każdym poczynaniem człowieka; w pewien rodzaj fatalizmu ludzkiej egzystencji? Wydaje

${ }^{2}$ Zob. tenże, Zmierzch bożyszcz, czyli jak się filozofuje młotem, przeł. P. Pieniążek, Zielona Sowa, Kraków 2005, s. 20.

${ }^{3}$ Tamże, s. 39.

${ }^{4}$ Zob. tamże. 
się, że stwierdzenie, iż los człowieka jest związany z przeznaczeniem całości stawania się świata, nie daje się pogodzić z twierdzeniem o samym stawaniu się rzeczywistości. Stawanie się jest wielością - ujęte jako całość powinno prowadzić raczej do przekonania, że żyjemy w świecie absurdu i chaosu. Przyczynowość, którą zauważamy w świecie przyrody, Nietzsche uważa za sfalsyfikowaną, ponieważ jest konstrukcją w sposób nieuzasadniony nałożoną na stawanie się człowieka ${ }^{5}$. Założenie stawania się w filozofii Nietzscheańskiej nie dopuszcza żadnych praw jako bezwzględnie obowiązujących, ukazując je jedynie jako użyteczne fikcje. Czy zatem Nietzsche ujmuje los na równi z „magicznym” przeznaczeniem, które nie jest dane człowiekowi do zrozumienia?

Rozwiązanie problemu wątpliwej wiary Nietzschego w przeznaczenie odnajdujemy w jego książce Ludzkie, arcyludzkie, w której czytamy:

Niech się człowiekowi uda jeszcze w końcu nabyć przekonania filozoficznego o bezwarunkowej konieczności wszelkich postępków i zupełnej nieodpowiedzialności za nie i niech one wejdą w jego krew i ciało, a zniknie też i owa reszta zgryzot sumienia 6 .

Jak wynika z przytoczonego cytatu, przek onanie o przeznaczeniu, a nie przeznaczenie samo, ma rządzić losem człowieka. Przekonanie o przeznaczeniu zdejmuje z człowieka jarzmo odpowiedzialności moralnej, dając mu całkowitą swobodę działania. Nietzschemu chodzi zatem o wiarę w przeznaczenie, które faktycznie w stawaniu się nie występuje. Wydaje się, że człowiek

${ }^{5}$ Tenże, Dzieła wszystkie. Tom 13. Notatki z lat 1887-1889, przeł. P. Pieniążek, Officyna, Łódź 2012, s. 248.

${ }^{6}$ Tenże, Ludzkie, arcyludzkie, przeł. K. Drzewiecki, vis-á-vis/Etiuda, Kraków 2010, s. 103. 
wierzący w przeznaczenie może nie być odpowiedzialny za kształt swojej egzystencji. Wiara w przeznaczenie zdejmowałaby z człowieka odpowiedzialność za jego czyny i przerzucała ją na nieznany los. Jednocześnie, jeżeli przeznaczenie faktycznie nie istnieje, a człowiek w nie wierzy, to jego działanie jest całkowitą biernością. Człowiek skazuje się na przypadek, jako jedyny element fundujący kształt jego życiu. Jednak, jak wynika z siódmego fragmentu przedmowy do Ludzkie, arcyludzkie z 1886 roku, według Nietzschego człowiek powinien poddać się wierze w przeznaczenie, aby rozwiązać „zagadnienie hierarchii””.

Rozwiązanie „zagadnienia hierarchii” wymaga, aby człowiek uznał, iż „Tajemna władza i konieczność tego zadania rządzić będzie popod jego wszystkimi losami i w nich na podobieństwo ciąży nieświadomej - na długo, nim sam to zadanie zmierzy okiem i pozna je z imienia"8. Zatem człowiek musi spodziewać się, że „zadanie” ujawni mu się z czasem. Natomiast, gdy to już nastąpi, cała przeszłość nabierze charakteru koniecznego etapu wiodącego zarówno do rozpoznania owego zadania, jak i pewnej części rozwiązania „zagadnienia hierarchii”. W naszych rozważaniach celowo pominięty zostaje wątek znaczenia pojawiającego się wyżej „zadania” i „zagadnienia hierarchii”, gdyż na tym etapie ważne jest jedynie określenie sensu Nietzscheańskiego rozumienia losu.

Los jest dla człowieka, jak wynika z naszych rozważań, przypadkowością, którą człowiek ma rozpoznać jako celową. Oznacza to, że przypadkowość ma być koniecznością. Wydawać by się mogło, że w tym myśleniu pojawia się paradoks. Jednak ujęcie to jest możliwe, gdyż całkowita przypadkowość, będąca wynikiem przyjęcia tezy, iż świat jest bezkresnym stawaniem się, wymusza na

${ }^{7}$ Zob. tamże, s. 12.

${ }^{8}$ Tamże. 


\section{Pawet Pałasiński}

człowieku użyteczne ujęcie go jako czegoś zdeterminowanego. Nietzsche pisał wprost: „Charakter świata stającego się nie daje się sformułować, jest «fałszywy», «sprzeczny ze sobą». Poznanie i stawanie się wyłączają się", dlatego należy: „Nie «poznawać», lecz schematyzować - narzucić chaosowi tyle regularności i form, ile czyni zadość naszej potrzebie praktycznej”"10. Jednym ze sposobów owego „schematyzowania” stawania się przez człowieka jest właśnie ujęcie indywidualnej egzystencji jako celowej.

W książce Tak mówił Zaratustra Nietzsche wkłada w usta perskiego proroka słowa: „Tego miłuję, który ze swej cnoty czyni swą skłonność i swe fatum" "11. Ujęcie losu, jako zdeterminowanego przez cel, który niejako organizuje życie człowieka, odrzuca możliwość bierności. Cel, jeżeli tylko się człowiekowi ujawni, wymaga określonego działania. Odrzucona zatem została interpretacja, w myśl której człowiek ślepo zdaje się na los i bezczynnie poddaje się napływającym zdarzeniom uznając, iż wszystko dzieje się z konieczności, oraz że nie ma on żadnej możliwości wolnego działania. Wiara w przeznaczenie oznacza podporządkowanie się celowi. Pytanie, które domaga się w tym momencie odpowiedzi, dotyczy celu, który niejako wyrywa człowieka z przypadkowości stawania się i nadaje poniekąd sens jego własnej egzystencji.

Celem tym ma być „zadanie”, które wymusza pojawienie się „zagadnienia hierarchii”. Jakie to zadanie? Aby odpowiedzieć na to pytanie, posłużymy się pytaniem pomocniczym, które brzmi: jakie było to zadanie w przypadku Nietzschego? Pytanie to wydaje

9 Tenże, Wola mocy, przeł. K. Drzewiecki, S. Frycz, vis-á-vis/Etiuda, Kraków 2009, s. 220.

${ }^{10}$ Tamże, s. 219.

${ }^{11}$ Tenże, Tak mówił Zaratustra. Ksiązka dla wszystkich i dla nikogo, przeł. G. Sowiński, Zielona Sowa, Kraków 2005, s. 17. 
się zasadne, gdyż autor Ecce Homo pisał: „Moją formułą wielkości człowieka jest amor fati [...]"12. Pomyślmy, w jaki sposób Nietzsche zastosował formułę amor fati względem samego siebie. Jakie było zadanie, które postawił przed sobą bazylejski filozof, a które zniwelowało w nim świadomość wielu bolesnych chwil obecnych w jego życiu? Odpowiedzi na te pytania przybliżą nas do Nietzscheańskiego ujęcia istoty losu ludzkiej egzystencji. Ujęcia, które - co warto zaznaczyć - zakłada paradoksalną wiarę w przeznaczenie, mające miejsce $\mathrm{w}$ przesyconym przypadkowością stawaniu się świata.

\section{CIĄŻĄCY LOS SKAZANY NA ZAPOMINANIE}

Nietzsche pisał o swoim zadaniu w Ecce Homo:

Moje zadanie przygotowania chwili najwyższego opamiętania się ludzkości, wielkiego południa, gdy spojrzy wstecz i w dal, gdy wydobędzie się spod panowania przypadku i kapłanów i pytanie: dlaczego? po co? postawi po raz pierwszy jako całość [...] Zagadnienie co do pochodzenia wartości moralnych jest przeto dla mnie zagadnieniem pierwszorzędnym, bo jest warunkiem przyszłości człowieka ${ }^{13}$.

Owym „zadaniem” Nietzschego, o które wyżej pytaliśmy, a które organizowało całe jego życie, jest „przygotowanie chwili największego południa". Największe południe to moment najkrótszego cienia, a „cień” symbolizuje kłamstwo. Owym wielkim kłamstwem, które autor Zmierzchu bożyszcz chciał zdemaskować było twierdzenie, że świat jest bytem, a nawet, że coś takiego jak „byt w ogóle" istnieje. Nietzsche zadawał się wierzyć, że gdy kłamstwo

\footnotetext{
${ }^{12}$ Tenże, Ecce..., s. 32.

${ }^{13}$ Tamże, s. 53.
} 
to zostanie obalone, ludziom uwidoczni się prawdziwa natura świata, która polega na stawaniu się. W momencie „najwyższego opamiętania się ludzkości" stanie się również jasne, że życie człowieka nie ma żadnego, z góry narzuconego celu ${ }^{14}$. Dlaczego Nietzsche chciał ukazać ludziom, że w świecie nie może być odnaleziony żaden trwały cel? Innymi słowy: jaki celce miał filozof w ukazaniu bezcelowości stawania się?

Cel Nietzschego - owo wyzwolenie ludzkości z fałszywego przekonania o celu, jedności i bycie świata - prowadzi do nihili$z u^{15}$. Jednak uwolnienie świata od interpretacji, która niejako zakłada logiczność świata czy pewien determinizm, daje człowiekowi prawo do nieskrępowanego tworzenia objaśnień tej rzeczywistości, czyli „schematyzowania” stawania się. Również w przypadku myślenia człowieka o jego własnym życiu jest obecna owa wolność interpretacyjna. Bezcelowość stawania się pozwala na tworzenie celów przez ludzi bez żadnego ich ugruntowania, czy to $\mathrm{w}$ filozofii, nauce, religii czy nawet $\mathrm{w}$ ogólnie przyjętym przez społeczeństwo modelu. Ważne jest jedynie - jak się zdaje - aby cel, który człowiek wybierze, został wybrany na wieczność; aby człowiek uczynił zeń „swe fatum”. Pojawia się jednak pytanie, jak skłonić zmiennych w przekonaniach ludzi do przyjęcia jednego celu - nawet nieważne jakiego - na całe życie? Co spowoduje, że ludzie nie wycofają się z raz podjętych decyzji i ustanowionych celów? Odpowiedź na to pytanie jest oczywista - nic.

Rozumienie przez człowieka celu egzystencji jest zmienne. Człowiek odkrywa cel swojej egzystencji z biegiem czasu. Zmiana celu każe ująć przeszły cel, jako element przeznaczenia, które

${ }^{14}$ Zob. tenże, Wola..., s. 16.

${ }^{15}$ Zob. tenże, Zapiski o nihilizmie (z lat 1885-1889), przeł. G. Sowiński, [w:] Wokót nihilizmu, red. G. Sowiński, Wydawnictwo A, Kraków 2001, s. 98. 
doprowadziło do uświadomienia sobie aktualnego celu. Wydaje się, że pytanie, na które należy teraz poszukiwać odpowiedzi, brzmi: jak ująć zdarzenia, których człowiek nie akceptuje, które uważa za szkodliwe czy wręcz złe? Życie dostarcza nam wielu zdarzeń, których nie da się zinterpretować jako koniecznych dla osiągnięcia przez człowieka jakiegokolwiek celu - jak podejść do tego typu doświadczeń? Nietzsche pisał:

By określić ten stopień, a przezeń potem granicę, na której przeszłość zapomniana być musi, jeśli nie ma się stać teraźniejszości grabarzem, trzeba by wiedzieć dokładnie, jak wielka jest moc plastyczna pewnego człowieka, narodu, kultury; mam na myśli ową siłę osobliwego rośnięcia z siebie, przetwarzania i wcielania przeszłości i obcości, gojenia ran, zastępowania strat, kształtowania z siebie form rozbitych ${ }^{16}$.

Z przytoczonego cytatu zdaje się wynikać, że im więcej siły ducha ma człowiek, tym więcej jest w stanie znieść zła pojawiającego się w jego życiu. Oznacza to, że człowiek o dużej „mocy plastycznej” potrafi ująć zło jako konieczność, czyli jako element jego przeznaczenia.

Co istotne, u każdego człowieka czy w każdej zbiorowości ludzkiej granica pomiędzy tym, co może zostać ujęte jako część fatum, a tym, co nie może być tak ujęte, jest różna. Owa granica zależy od „mocy plastycznej”, która - jak wskazuje Józef Pietrzak - była jednym z pojęć, które Nietzsche zastąpił później terminem „wola mocy"17. Wydaje się, że człowiek kierując się wolą mocy czyli wolą panowania, tu nad rozumieniem swej własnej historii jest zdolny nadawać swojej przeszłości interpretację wedle wła-

${ }^{16}$ Tenże, Niewczesne rozważania, przeł. L. Staff, Zielona Sowa, Kraków 2006, s. 66.

${ }^{17}$ Zob. J. Pietrzak, Nietzscheańska koncepcja wychowania, Wydawnictwo Uczelniane, Słupsk 1997, s. 45. 
snego uznania. Działanie takie umożliwia życie w świecie, który ma sens i wartość, ponieważ jest celowy i niejako zgodny z oczekiwaniami człowieka. Podejście to wydaje się tylko teoretyczne i nie pokazuje dokładnie, jak w konkretnym przypadku uporać się z ciążącą przeszłością. Dlatego interesujące wydaje się pytanie, jaki był stosunek Nietzschego do jego własnej przeszłości.

Nietzsche o swoim stosunku do przeszłości pisał:

Ja sam nie cierpiałem nigdy z powodu tego wszystkiego; co konieczne, nie dotyka mnie; amor fati jest moją najwnętrzniejszą naturą ${ }^{18}$.

Z przytoczonych słów autora Ecce Homo zdaje się wynikać, iż był on w stanie przyswoić całość swojego doświadczenia i ująć je jako część swojego koniecznego losu, czyli zinterpretować je jako przeznaczenie. Znany jest fakt, iż Nietzsche cierpiał na wiele dolegliwości już od wczesnego dzieciństwa ${ }^{19}$. Dolegliwości te, z różnym nasileniem towarzyszyły mu przez całe świadome życie, by doprowadzić go w końcu do całkowitej zapaści umysłowej w roku 1889. Bazylejski filozof - w zgodzie z tym, co pisał o „mocy plastycznej" - interpretował nawiedzające go choroby jako objaw przezwyciężającego je zdrowia ${ }^{20}$. Wynika z tego, że formułę amor fati Nietzsche przemyślał i skonfrontował z własnym doświadczeniem. W Wiedzy radosnej jej autor pisze:

${ }^{18}$ F. Nietzsche, Ecce..., s. 73.

${ }^{19}$ Zob. T. Gómez, Człowiek i twórca Fryderyk Nietzsche, przeł. G. Ostrowski, Muza, Warszawa 2007, s. 27-28.

${ }^{20}$ Zob. F. Nietzsche, Dzieła..., s. 440. Na uwagę zasługują również rozważania Karla Jaspersa o stosunku Nietzschego do jego własnej choroby (zob. K. Jaspers, Nietzsche. Wprowadzenie do rozumienia jego filozofii, przeł. D. Stroińska, Officyna, Łódź 2012, s. 142-143). 
Wszystko, co jest mi pokrewne, w przyrodzie i historii, przemawia do mnie, chwali mnie, popycha mnie na przód, pociesza mnie - wszystkiego innego nie słyszę lub zapominam wnet $^{21}$.

Nietzsche pisał zatem wprost, że wszystko działa niejako dla niego, a wszystko inne: albo jest przez niego pomijane, jako nieistotne, albo opada w odmęty zapomnienia. Chociaż z przytoczonych wyżej cytatów dowiadujemy się jedynie o tym, co Nietzsche zaakceptował jako część swojego losu, a nie o tym, co zostało przez niego zapomniane, nie możemy jednak wymagać, aby filozof pisał o tym, co zapomniał. Samo zapominanie uwidacznia się w słowach Nietzschego: „zapominam wnet”, co potwierdza nasze przypuszczenie o selektywnym ujmowaniu przez autora Wiedzy radosnej swojego własnego życia. Wydaje się, że autor Tak mówił Zaratustra przekazywał to ujęcie w swoich pismach, czyniąc zeń część swojej filozofii, gdy pisał o „mocy plastycznej” i zapominaniu.

Zapominanie - według Nietzschego - jest człowiekowi niezbędne, aby mógł ustanowić swój cel i działać w świecie ${ }^{22}$. Jednocześnie zapominanie polega na modelowaniu czy wręcz deformowaniu pamięci, na selektywnym, intencjonalnym, a co najważniejsze aktywnym ${ }^{23}$ uczestniczeniu $\mathrm{w}$ kreowaniu rozumienia swojego miejsca w świecie. Zatem nasze „poznanie pracuje jako narzędzie mocy" ${ }^{24}$ - interpretujemy swoje życie i świat.

Fryderyk Nietzsche pisał w Woli mocy:

${ }^{21}$ F. Nietzsche, Wiedza radosna, przeł. L. Staff, Zielona Sowa, Kraków 2006, s. 123.

${ }^{22}$ Zob. tenże, Niewczesne..., s. 65-66.

${ }^{23}$ Zob. tenże, Z genealogii moralności. Pismo polemiczne, przeł. L. Staff, Zielona Sowa, Kraków 2003, s. 41.

${ }^{24}$ Tenże, Wola..., s. 217. 
Chodzi tu o możliwie szybką redukcję zjawisk, o ekonomiczność, akumulację nabytego skarbu poznania (tj. świata, który przywłaszczyliśmy sobie i uczynili poręcznym)... ${ }^{25}$.

Świat „poręczny” to taki, w którym człowiek odbiera swoje życie, jako istotne ze względu na cel, jaki mu nadał. Takie poczucie daje właśnie wiara w amor fati, jako ujęcie gwarantujące celowość ludzkiej egzystencji, pomimo że jest ona w istocie iluzyjna, gdyż w stawaniu się nie ma żadnego celü ${ }^{26}$.

Należy jednak zapytać, czy Nietzschemu chodziło tylko o otwarcie „wielkiego morza” interpretacji czekających na człowieka, który chciałby rozumieć swoje życie w perspektywie czekającego nań przeznaczenia? Czy może Nietzscheańskie amor fati nierozerwalnie wiąże się z innymi wątkami autora Tak mówił Zaratustra i jest od nich zależne, tak jak jest zależne od założenia stawania się świata?

\section{POWRÓT LOSU W „WIELKIM ROKU STAWANIA SIĘ”}

Wiara w amor fati, o czym była mowa już wcześniej, mimo że wydaje się wprowadzać złudzenie celowości ludzkiego istnienia, to zdaje się nie wynikać ze stawania się świata. Stawanie się wymusza poczucie, iź świat nie ma celu, a wraz z nim ludzkie życie zostaje niejako wchłonięte w otchłań przypadkowości i bezznaczeniowości. Stawanie się w swojej nieokreśloności może powodować erozję wszystkich wartości, w tym wartości życia człowie$\mathrm{ka}^{27}$. Nietzscheańska filozofia stanęła zatem przed wyzwaniem

${ }^{25}$ Tamże, s. 131.

${ }^{26}$ Tenże, Pisma pozostałe, przeł. B. Baran, Aletheia, Warszawa 2009, s. 312.

${ }^{27}$ Zob. tenże, Zapiski o nihilizmie (z lat 1885-1889), przeł. G. Sowiński, [w:] Wokót nihilizmu..., s. 97-98. 
uczynienia życia człowieka wartościowym, przy jednoczesnym założeniu stawania się jako faktycznej rzeczywistości. Wydawać by się mogło, że stawanie się jest rządzone przez ślepy przypadek, a istnienie człowieka jest w nim skazane na absurd i brak znaczenia. Jednak, jak pamiętamy, autor Tak mówił Zaratustra proponuje interpretację stawania się jako szczególnego rodzaju całości rządzonej przez przypadek. Nietzsche zakłada dalej, że całość ta jest wewnętrznie ograniczona przez to, że jest skończoną ilością energii, a rozgrywa się $\mathrm{w}$ nieskończonym czasie ${ }^{28}$. Te dwa założenia względem stawania się: iż przebiega ono wiecznie oraz że jest wewnętrznie ograniczone, mają prowadzić do koncepcji wiecznego powrotu tego samego, która nie jest sprzeczna z ideą stawania się.

Co ciekawe, założenia te nie posiadają ugruntowania w samym stawaniu się, Nietzsche jednak je przyjmuje, gdyż bez nich wyobrażenie stawania byłoby „bezużyteczne”29. Ich użyteczność uwidacznia się zaś w tym, że prowadzą one do koncepcji wiecznego powrotu. Pytanie, na które musi zatem odpowiedzieć, brzmi: co takiego powoduje koncepcja wiecznego powrotu tego samego w myśleniu człowieka o świecie i nim samym? Czy powoduje reaktywację wartości życia, którą stawanie się, jak się wydaje, unieważniło? Aby odpowiedzieć na te pytania musimy przyjrzeć się niektórym interpretacjom Nietzscheańskiej koncepcji wiecznego powrotu tego samego.

Na wstępie należy zaznaczyć, że koncepcja wiecznego powrotu Nietzschego przedstawia się (w dużym uproszczeniu) następująco: świat, jako skończona ilość siły przy nieskończonej ilości czasu musi odtwarzać wszystkie stany nieskończoną ilość razy. Jednak, jak zauważa Gilles Deleuze, w tej postaci koncepcja wiecz-

\footnotetext{
${ }^{28}$ Zob. tenże, Pisma..., s. 423.

${ }^{29}$ Tamże.
} 
nego powrotu jest „banalna i przerażająca” zarazem ${ }^{30}$. Deleuze proponuje interpretację Nietzscheańskiego wiecznego powrotu, jako „Bytu selektywnego”, co oznacza, że w stawaniu się działa niejako siła odśrodkowa, która odrzuca nihilizm i reaktywnośćs ${ }^{31}$. Koncepcja wiecznego powrotu ma zatem prowadzić człowieka do afirmacji i aktywności.

Inną interpretację wiecznego powrotu przedstawił Martin Heidegger. Autor Bycia i czasu w idei wiecznego powrotu widzi Nietzscheańskie określenie bytu w całości, który w swym stawaniu się ma charakter woli mocy ${ }^{32}$. Wieczny powrót utrwala to, co nietrwałe (w tym też ulotne życie ludzkie), jako część procesu powtarzania, co jest - jak tłumaczy Heidegger - przeszkodą dla stawania $\mathrm{się}^{33}$. Z wzajemnego ścierania się chaosu stawania się, który powoduje nietrwałość, oraz utrwalającego wiecznego powrotu wynika wola mocy, czyli sam człowiek, który stając się dąży zarazem do utrwalenia. Człowiekiem, który dąży do utrwalenia, czyli „odnosi się do bytu, który jako taki jest wolą mocy, a w całości wiecznym powrotem tego samego", jest nadczłowiek ${ }^{34}$. Nadczłowiek jest zaś dla Nietzschego wolny od nihilizmu i - jako taki odbiera swoje życie jako posiadające wartość pozytywną, czyli je afirmuje.

Wieczny powrót przemienia chaos stawania się w cykl, w którym wszystkie elementy tego procesu są jego podstawą. W takim wypadku wszystkie chwile $\mathrm{w}$ tym cyklu są konieczne dla jego

${ }^{30}$ Zob. G. Deleuze, Nietzsche, przeł. B. Banasiak, Officyna, Łódź 2012, s. 81.

${ }^{31}$ Zob. tamże, s. 81-82.

${ }^{32}$ Zob. M. Heidegger, Nietzsche, t. 2, przeł. A. Gniazdowski et al., Wydawnictwo Naukowe PWN, Warszawa 1998-1999, s. 274.

${ }^{33}$ Zob. tamże, s. 281.

${ }^{34}$ Zob. tamże, s. 282. 
zachowania. Wieczny powrót tworzy zatem coś, co możemy nazwać chaosem konieczności. „Chaosem”, gdyż dla człowieka w owym procesie następstwo kolejnych zjawisk jawi się jako przypadkowe; a „konieczności”, gdyż w „wielkim roku stawania się" wszystko następuje tak samo jak było wcześniej i będzie w przyszłości. Przyjęcie koncepcji wiecznego powrotu tego samego, jak opisywał to Nietzsche w Wiedzy radosnej, może być uzależnione od jednej chwili, którą człowiek uzna za pozytywną i dla siebie istotną $^{35}$. Nietzsche przekonywał, iż jedna istotna chwila miałaby prowadzić do afirmacji całego życia. Wynikać to ma z dosyć prostego założenia, że ludzka chęć powrotu owej chwili zmusza do przyjęcia koncepcji wiecznego powrotu tego samego, a dalej do uznania, że wszystkie inne chwile w życiu są nierozerwalnie związane z tą ważną chwilą. Wieczny powrót tego samego staje się „doktryną totalnej i bezwarunkowej afirmacji”36.

Wydaje się, iż koncepcja wiecznego powrotu, niezależnie czy interpretowana jako utrwalanie tego samego bądź jako „Byt selektywny", czy afirmacja całości życia dzięki jednej chwili, ma doprowadzić człowieka do afirmacji własnej egzystencji. Afirmacja ta jest afirmacją stawania się, czyli jakiegoś ujęcia losu człowieka w świecie, co wydaje się być zbieżne z ideą amor fati.

\section{KREACJA LOSU DLA PRZYSZŁOŚCI}

Powróćmy teraz do wspomnianej kwestii „zadania” i „zagadnienia hierarchii", o których pisał autor Ecce Homo ${ }^{37}$. Zadanie

${ }^{35}$ Zob. F. Nietzsche, Wiedza..., s. 179.

${ }^{36}$ Zob. S. Łojek, Obrona Nietzschego. Rzecz o odpowiedzialności, Antyk, Kęty 2002, s. 191.

${ }^{37}$ Zob. F. Nietzsche, Ecce..., s. 53. 
Nietzschego - uwolnienie od iluzji bytu - odbiera człowiekowi podstawę do działania. Moralność, religia czy filozofia są jedynie kłamstwem - nie ma żadnego gruntu, na którym człowiek mógłby określić kierunek działania. Karl Jaspers pisał w swojej książce poświęconej filozofii Nietzschego:
Atakując to, co żywe w samoświadomości człowieka jako prawo moralne i wolność, zaprzeczając temu, Nietzsche pragnie uchwy- cić autentyczne bycie człowiekiem, stawiając nowe wymagania. To, co nazywało się wolnością, staje się dlań «twórczością» ${ }^{38}$.

Jaspers zwraca uwagę na fakt, że Nietzscheańskie wyzwolenie człowieka spod panowania fałszywego przekonania, iż istnieje coś stałego w świecie, zmusza go do przyjęcia twórczej drogi dla zrozumienia celu własnego życia i świata. W sposób twórczy człowiek ma znaleźć swoje fatum i mu się podporządkować, czyniąc jednocześnie ze swojego życia zadanie. Los człowieka to zatem twórcze zmaganie się z przypadkowością, będącą istotą stawania się. Człowiek swoją wolą ogarnia chaos, schematyzuje go i nadaje mu sens. W Tak mówił Zaratustra Nietzsche pisał:
A coś, co nazwaliście światem, niech zostanie dopiero stworzone przez was: niech się stanie waszym rozumem, waszym obrazem, waszą wolą, waszą miłością! Zaprawdę dla waszej szczęsności, poznający $!^{39}$

Poznanie świata nie jest możliwe. Człowiek może jedynie wytworzyć użyteczną fikcję: interpretację, którą nazwie światem. Wydaje się, że może być nieskończenie wiele obrazów, schematów stawania się, które ludzie są w stanie wykształcić. Dodatkowo,

\footnotetext{
${ }^{38}$ K. Jaspers, Nietzsche..., s. 165.

${ }^{39}$ F. Nietzsche, Tak mówit..., s. 86.
} 
wszystkie te interpretacje świata będą tak samo nieadekwatne do jego prawdziwej natury, czyli stawania się. Jednak Nietzschemu nie chodzi tu o prawdę, tylko o świadomość, że człowiek jest twórcą swojego rozumienia świata. Świadomość ta jest przywilejem, przejawem wolności, ale również wymaga od człowieka odpowiedzialności ${ }^{40}$. Nad człowiekiem nie ma nic, co mówiłoby, jaki świat jest, jak człowiek powinien żyć, do czego dążyć, a czego się wystrzegać. Każdy podejmowany przez człowieka wybór jest jego wyborem, dlatego jeżeli wybierze źle, to odpowiada jedynie przed sobą i siebie może za to winić. Człowiek jest zatem odpowiedzialny sam przed sobą za kształt swojego życia. Z tego powodu Nietzsche pisał: „Cierpieć zaś przez rzeczywistość to tyle, co być "unieszczęśliwioną» rzeczywistością..." ${ }^{41}$. Człowiek jest twórcą rzeczywistości: jako jej interpretator i jako jej twórca odpowiada za jej kształt.

Jak pamiętamy, „zadanie” Nietzschego to nic innego jak uwolnienie ludzi od iluzji świata uporządkowanego, gdzie wszystko zostało bądź zostanie uporządkowane według niezmiennych, wiecznych praw. Wizja świata bytu, która jest konsekwencją takiego dążenia do uporządkowania, prowadzić ma - według autora Tak mówił Zaratustra - do pojawienia się „ostatniego człowieka”, czyli człowieka, który nie jest twórczy. Świat „ostatniego człowieka” opisywał Nietzsche ostro w słowach: „Żadnych pasterzy, jedno stado! Każdy chce tego samego, co inni; każdy jest taki sam, jak inni: kto odczuwa inaczej, ten z własnej woli idzie do domu dla obłąkanych" ${ }^{42}$. Ludzie przyjąwszy jedno rozumienie świata i celu życia stają się całkowicie nietwórczy. Ludzie tacy płyną bezreflek-

\footnotetext{
${ }^{40}$ Zob. tenże, Z genealogii..., s. 43.

${ }^{41}$ Tamże.

${ }^{42}$ Tenże, Tak mówił..., s. 19.
} 
syjnie przez życie, zadowoleni, że nie muszą podejmować żadnego trudu, by określić swoje miejsce w świecie.

W przypadku „ostatniego człowieka” odsłania się różnica pomiędzy ujęciem rzeczywistości jako posiadającej cel przez ludzkość i przez konkretnego człowieka. Ludzkość przyjąwszy jeden cel, który da jej szczęście ${ }^{43}$, popada w bierność. Natomiast człowiek, który sam określa swój cel, jest twórczy, a przez to, że nie ustaje w swojej twórczości - którą wymusza na nim samo życie, dostarczając coraz więcej materiału do zinterpretowania - jest ciągle aktywny.

Co ciekawe, w książce Wędrowiec i jego cień Nietzsche pisał:

Musisz wierzyć w fatum - do tego może cię zmusić nauka. Co jednak w tobie z tej wiary wyrośnie - tchórzostwo, poddanie się lub wielkoduszność i prawość - to świadczy o glebie, w którą rzucono owo nasienie; lecz nie o samym nasieniu - albowiem z niego może wyróść wszystko, co chcesz ${ }^{44}$.

Nauka - czyli pewien sposób ujęcia stawania się świata - daje zatem możliwość dla uznania, że wszystko jest zdeterminowane, że fatum rzeczywiście rządzi losem człowieka. Zatem nauka może służyć za przesłankę: albo dla biernego oczekiwania nieubłaganego następstwa zjawisk - determinizmu, albo do wiary w amor fati. Świat widziany jako zdeterminowany przez fatum to świat, w którym ludzka egzystencja posiada sens.

Nietzsche chciał uwolnić ludzi od iluzji i wskazać im drogę twórczego kreowania świata niejako dla nich samych. Świat uwolniony od iluzji bytu jest wymarzonym gruntem dla twórczej

${ }^{43}$ Zob. tamże, s. 20.

${ }^{44}$ Tenże, Wędrowiec i jego cień, przeł. K. Drzewiecki, vis-á-vis/Etiuda, Kraków 2010, s. 132. 
interpretacji. Owo interpretowanie ma prowadzić do amor fati, umiłowania swojego losu, jako nierozerwalnie związanego z indywidualnym celem życia każdego człowieka. Pytanie, na które jeszcze nie zdołaliśmy odpowiedzieć brzmi: czym, w stosunku do „zadania” Nietzschego, jest „zagadnienie hierarchii”? Nietzsche pisał: „[...] filozof ma rozwiązać problemat wartości, ma ustanawiać stopnie wartości” ${ }^{45}$, co ma dopomóc w „zadaniu przyszłości”46. Wydaje się, że w „zagadnieniu hierarchii” może chodzić o hierarchię wartości. Jeżeli człowiek ustanawia cel dla swojego życia, dzięki czemu czyni je sensownym, to w jakim stosunku do tego celu sytuują się wartości? Wartości nie posiadają ustalonego znaczenia, tak samo jak wszystko w stawaniu się. Wartości pochodzą bezpośrednio z życia człowieka, tworzą się wraz z ludzkimi wyborami - wartości są przeto uwarunkowane przez życie ${ }^{47}$. Natomiast rozumienie życia jest zależne od celu, jaki człowiek mu nada. Zatem „zagadnienie hierarchii” jest podporządkowane „zadaniu", jakie człowiek nada własnemu życiu.

Możemy zapytać, czy Nietzsche postulował jakiś konkretny cel poza oczywiście twórczym ujmowaniem własnego życia przez człowieka - który miałaby przyjąć cała ludzkość bądź każdy człowiek. Zdawać by się mogło, że odpowiedź na to pytanie jest negatywna. Nietzsche dążył do wytworzenia postawy, w której człowiek odkryje w sobie twórcę i będzie kreować swoje cele. Jak pisał autor Zmierzchu bożyszcz: „Trzeba wiedzieć, czego się chce i że się chce" ${ }^{48}$. Wiedza, że się chce, jest już wyzwoleniem, bo wskazuje na aktywność zamiast biernego podporządkowania się.

\footnotetext{
${ }^{45}$ Tenże, Z genealogii..., s. 38 .

${ }^{46}$ Zob. tamże.

${ }^{47}$ Zob. K. Michalski, Płomień wieczności, Znak, Kraków 2007, s. 26-29.

${ }^{48}$ F. Nietzsche, Zmierzch..., s. 11.
} 
Ideał twórczego rozwoju ujęty zostaje w filozofii Nietzscheańskiej pod symboliczną postacią idei „nadczłowieka”. Wydaje się, że ta właśnie koncepcja była najważniejsza w myśleniu Nietzschego. Należałoby więc uznać, że idea nadczłowieka była głównym zadaniem Nietzschego, gdyż zmiana sposobu myślenia ludzi miała gwarantować przyszłość zupełnie inną, bo przesyconą twórczym zmaganiem się ludzi z wydarzającym się światem. Nietzsche mówił o tym wprost ustami perskiego proroka z Tak mówił Zaratustra:

Chcę uczyć ludzi, co stanowi sens ich bytu: sensem tym jest nadczłowiek $^{49}$.

Amor fati jest jednym z elementów układanki, która składa się na wizję tego, czym jest $\mathrm{w}$ filozofii Nietzschego nadczłowiek. Koncepcja umiłowania losu daje człowiekowi poczucie harmonii z otaczającą go rzeczywistością. Dalej, poczucie harmonii umożliwia człowiekowi rozwój nieograniczony przez poczucie niesprawiedliwości, które rodzi się w momencie wydarzeń uznawanych przez niego za bezwzględnie złe. Faktyczna przypadkowość w filozofii Nietzscheańskiej zostaje zastąpiona poczuciem konieczności, które wydaje się pożyteczne dla rozwoju człowieka twórczego.

\section{PODSUMOWANIE}

Nietzsche, którego często przedstawia się jako nieubłaganego demaskatora wszystkich iluzji, jakie rządzą życiem człowieka, w swojej koncepcji amor fati odsłania konieczność iluzji w życiu człowieka. Koncepcja umiłowania losu zmienia ludzkie ujęcie rzeczywistości: z absurdalnej przypadkowości na złudne poczucie

${ }^{49}$ Tenże, Takmówit..., s. 21. 
konieczności wszystkiego, co się wydarza. Nie sposób zaprzeczyć, że dla człowieka poczucie sensu jest istotne, a iluzoryczny charakter idei amor fati budzi wątpliwości. Należy jednak przyznać, że, zakładając stawanie się świata, Nietzsche nie miał dużego pola manewru w tej kwestii.

Koncepcja amor fati jest jednym ze sposobów na nadanie ludzkiemu życiu wartości ze względu na nie samo. Ową wartość każdy musi stworzyć sobie sam. Nietzsche wskazał kierunek, natomiast od każdego człowieka zależy, co zrobi ze swoim życiem. Czy ludzkość popadnie w bierność i konformizm, czy też wykaże się twórczą odwagą - pozostaje kwestią otwartą w życiu każdego człowieka. Koncepcja amor fati może być impulsem do zmiany nastawienia do życia i świata, lecz jej trwałe obowiązywanie uzależnione jest jedynie od wiary człowieka w tę ideę. Należy także podkreślić, że w filozofii autora Tak mówił Zaratustra nie znajdziemy szczegółowych dyrektyw mówiących ludziom, jak żyć. Konkretów Nietzsche nie podaje, bo ich, jego zdaniem, nie ma. Dlatego też pisał:

«To jest moja droga - a wasza jest która»: tak odpowiadam wszystkim, którzy pytali mnie «o drogę»! Nie ma bowiem czegoś takiego jak droga w ogóle! $!^{50}$.

Wydaje się zatem, że Nietzsche pisał o tym, jak sam żył. Dawał w ten sposób przykład, jak żyć w harmonii i kochać swój trudny los. Co ważne, nie starał się wprowadzać w tym zakresie żadnego przymusu.

${ }^{50}$ Tamże, s. 191. 


\title{
FRIDERICK NIETZSCHE'S AMOR FATI (NECESSITY AND FORTUITOUSNESS OF HUMAN'S DESTINY)
}

\begin{abstract}
SUMMARY
This article is about the concept of amor fati in the Friedrich Nietzsche's philosophy. In philosophy of Beyond Good and Evil the author's idea of amor fati combines reflections on fortuitousness and necessity in the context of human life. In this paper, the author attempts to show the significance of this idea by the interpretation of Nietzsche's statements about the following concepts: fortuitousness and necessity. The other issue is Nietzsche's writing about his own attitude to life and the world. The amor fati idea appear to be an existential challenge that Nietzsche confronts with people who want to see their life as meaningful. By Nietzsche fortuitousness as the essence of the world is subordinate to the human life requiring the purpose. The amor fati concept appears as one way of life in the world without purpose.
\end{abstract}

\section{KEYWORDS}

amor fati, necessity, fortuitousness, Übermensch, Nietzsche F. 